\title{
Erratum
}

Naunyn-Schmiedeberg's Arch Pharmacol (1989) 339:514-521

\section{N-Methyl-D-Aspartate (NMDA) receptor-mediated stimulation of noradrenaline release, but not release of other neurotransmitters, in the rat brain cortex: receptor location, characterization and desensitization}

K. Fink, M. Göthert, G. Molderings, and E. Schlicker

Institut für Pharmakologie und Toxikologie der Rheinischen Friedrich-Wilhelms-Universität Bonn, Reuterstrasse 2B,

D-5300 Bonn 1, Federal Republic of Germany

Due to an unfortunate error, the concentration of MK 801 "10 $\mu \mathrm{mol} / \mathrm{l}$ " in the legend to Fig. 5 is incorrect. It should have read " $10 \mathrm{nmol} / \mathrm{l}$ ". 